\title{
Growth inhibition of cholic acid-conjugated polyethylenimine 25K/ p53-EGFP complexes on human carcinoma cells
}

\author{
Wanlop Weecharangsan ${ }^{1 *}$, Nattisa Niyomtham ${ }^{2}$, Boon-ek Yingyongnarongkul ${ }^{2}$, Praneet Opanasopit ${ }^{3}$, Robert J. Lee ${ }^{4}$ \\ ${ }^{1}$ Department of Pharmaceutical Technology, Faculty of Pharmacy, Srinakharinwirot University, Nakhon Nayok 26120, Thailand. \\ ${ }^{2}$ Department of Chemistry and Center of Excellence for Innovation in Chemistry, Faculty of Science, Ramkhamhaeng University, Bangkok, Thailand. \\ ${ }^{3}$ Pharmaceutical Development of Green Innovations Group (PDGIG), Faculty of Pharmacy, Silpakorn University, Nakhon Pathom, Thailand. \\ ${ }^{4}$ Division of Pharmaceutics and Pharmacology, College of Pharmacy, The Ohio State University, Columbus, OH.
}

\section{ARTICLE INFO \\ Received on: 19/11/2020 \\ Accepted on: 27/02/2021 \\ Available online: 05/04/2021}

\section{Key words:}

Polyethylenimine $25 \mathrm{~K}$, cholic acid, p53, gene delivery, cancer.

\begin{abstract}
Cholic acid-conjugated polyethylenimine 25K (PEI 25K-CA) was synthesized and characterized for gene delivery of its buffer capacity, PEI 25K-CA/plasmid DNA complex, zeta potential and particle size, transfection efficiency, cytotoxicity, and carcinoma cell growth inhibition. PEI 25K-CA was complexed with plasmid DNA at the ratio above 0.25/1. PEI 25K-CA/p53-EGFP (p53-enhanced green fluorescent protein) and PEI 25K/p53-EGFP had the particle sizes of $238.2 \pm 3.1-529.1 \pm 3.6 \mathrm{~nm}$, and the zeta potential of $3.7 \pm 1.6-4.3 \pm 0.2 \mathrm{mV}$, respectively. The particle size of the complexes increased with the period of time. PEI 25K-CA/p53-EGFP had transfection efficiency as PEI 25K/ p53-EGFP. The cytotoxicity of PEI 25K-CA was dependent on the concentration of the polymer. The growth inhibition activity was dependent on the dose of p53-EGFP. PEI 25K-CA/pEGFP had better colloidal stability than PEI 25K-CA/ pEGFP. This study concluded that PEI 25K-CA had efficient gene delivery activity as PEI and had lower cytotoxicity and more colloidal stability than PEI 25K.
\end{abstract}

\section{INTRODUCTION}

P53 induces apoptosis, cell cycle arrest, and senescence (Kaiser and Attardi, 2001). P53 interacts with the antiapoptotic bcl-2 family, liberates cytochrome $\mathrm{C}$, and leads to trigger of caspase cascade and ultimately apoptosis (Marchenko and Moll, 2014). P53 accumulates in the mitochondria and interacts with cyclophilin $\mathrm{D}$, which triggers the opening of mitochondrial permeability transition pore, which leads to necrosis (Marchenko and Moll, 2014).

The cationic polymer has been reported to deliver plasmid DNA including PAMAM (polyamidoamine), PEI, and chitosan (Cao et al., 2019; Chen et al., 2019b; Liufu et al., 2019). Low toxicity has been considered for use in gene delivery. High MW PEI has been widely used as a gene delivery vector (Wang

\footnotetext{
"Corresponding Author

Wanlop Weecharangsan, Department of Pharmaceutical Technology, Faculty of Pharmacy, Srinakharinwirot University, Nakhon Nayok, Thailand,E-mail:wanlop@g.swu.ac.th
}

et al., 2015). However, because of its high cytotoxicity, its use was limited in vivo (Hao et al., 2019).

In this study, PEI-CA/p53-EGFP was synthesized, characterized, and evaluated for delivering plasmid p 53 into HeLa cells.

\section{MATERIALS AND METHODS}

\section{Materials}

Polyethylenimine 25K (PEI 25K) and cholic acid were purchased from Sigma-Aldrich (St. Louis, MO). ${ }^{1} \mathrm{H}$ nuclear magnetic resonance (NMR) spectra were analyzed on an Bruker Avance $400 \mathrm{MHz}$ spectrometer (MPA, Bruker, Billerica, MA). IR spectra were carried out on a Perkin-Elmer FTIR spectrum 400 spectrometer (PerkinElmer, Inc., Waltham, MA). Cell culture flask and plate were purchased from SPL Life Sciences (Gyeonggi-do, Korea). Cell culture medium and supplements were purchased from Invitrogen (Grand Island, NY, USA). Human cervical carcinoma cell line (HeLa) was obtained from American Type Culture Collection Rockville, MD). 
Synthesis of cholic acid-conjugated polyethylenimine $25 \mathrm{~K}$ (PEI 25K-CA)

The solution of cholic acid (1.9 $\mathrm{mg}, 0.0046 \mathrm{mmol})$, $N, N$-dicyclohexylcarbodiimide $(3.8 \mathrm{mg}, 0.0184 \mathrm{mmol})$, and 4-dimethylaminopyridine $(2.2 \mathrm{mg}, 0.0184 \mathrm{mmol})$ in $1 \mathrm{ml}$ of $N, N$ dimethylformamide was stirred for 15 minutes. A solution of PEI 25K (230 mg, $0.0092 \mathrm{mmol}$ ) in $4 \mathrm{ml}$ of dimethylformamide was added to the activated cholic acid solution under nitrogen. The reaction was carried out under stirring for 24 hours. The reaction mixture was diluted with $10 \mathrm{ml}$ of methanol and purified by Sephadex ${ }^{\mathrm{TM}} \mathrm{LH}-20$ using methanol as the eluting solvent. The collected fractions were dried by rotary evaporation and further dried under vacuum.

\section{Conjugation of PEI 25K-CA}

IR: $v_{\text {max }} 3,252,2,928,2,815,1,658,1,614,1,452,1,365$, $1,348 \mathrm{~cm}^{-1}$; ${ }^{1} \mathrm{H}$ NMR (400 MHz, $\left.\mathrm{D}_{2} \mathrm{O}\right): \delta 0.83$ (br s, 3H, H-18$\mathrm{CA}), 1.07$ ( $b r s, 3 \mathrm{H}, \mathrm{H}-19-\mathrm{CA}), 1.22-2.1$ ( $m, 30 \mathrm{H}$, methane, ethine, and methylene protons of CA), 2.57-3.42 [m, -NH-CH $\left.\mathrm{CH}_{2}-\mathrm{NH}-(\mathrm{PEI})\right], 3.79$ (br s, 1H, H-3-CA), 3.83 (br s, 1H, H-7$\mathrm{CA})$, and 3.96 (br s, 1H, H-12-CA).

\section{Measurement of buffer capacity of PEI 25K-CA}

PEI 25K-CA (1 : 0.5 molar ratio) was dissolved in $10 \mathrm{ml}$ of $0.9 \%$ sodium chloride solution at a concentration of $0.1 \mathrm{mg} / \mathrm{ml}$. PEI 25K-CA solution was titrated with $0.1 \mathrm{~N}$ hydrochloric acid solution. The $\mathrm{pH}$ of PEI 25K-CA solution was measured using a pH meter (Bench 700, Oakton Instrument, IL). The buffer capacity of PEI 25K-CA was calculated at a high region resistance of $\mathrm{pH}$ change by dividing the amount of hydrochloric acid of $\mathrm{pH}$ change (Sinko, 2006).

\section{Agarose gel electrophoresis}

The complex formation of the PEI 25K-CA and p53EGFP complex was examined using agarose gel electrophoresis. The weight ratios of PEI 25K-CA and p53-EGFP were 0.125, $0.25,0.5,1,2$, and 4 . The amount of p53-EGFP used was 0.25 $\mu \mathrm{g}$. PEI $25 \mathrm{~K}-\mathrm{CA} / \mathrm{p} 53-\mathrm{EGFP}$ complexes were run on $1 \%$ agarose in Tris boric EDTA (ethylenediaminetetraacetic acid) buffer at a voltage of $100 \mathrm{~V}$ for 15 minutes.

\section{Zeta potential and particle size}

The average zeta potential and particle size of PEI25KCA/p53-EGFP and PEI25K/p53-EGFP complexes were measured using Zetasizer (Malvern Instruments Ltd., Worcestershire, UK) at $25^{\circ} \mathrm{C}$. $50 \mu \mathrm{l}$ of complexes was diluted with $950 \mu \mathrm{l}$ of deionized water prior to measurement. The colloidal stability of the complexes was evaluated in deionized water and in $10 \%$ bovine serum albumin solution at $4^{\circ} \mathrm{C} \pm 2^{\circ} \mathrm{C}$.

\section{Transfection of PEI 25K-CA/p53-EGFP complexes and gene expression}

HeLa cells were seeded $\left(1.5 \times 10^{5}\right.$ cells $\left./ \mathrm{cm}^{2}\right)$ onto 6-well plates in $2 \mathrm{ml}$ of growth medium and grown for 24 hours. The cells were incubated with $1 \mathrm{ml}$ of PEI 25K-CA/p53-EGFP complexes, free nucleic acid, and PEI 25K/p53-EGFP complexes for 4 hours at $37^{\circ} \mathrm{C}$ under $5 \% \mathrm{CO}_{2}$ atmosphere. After incubation, the transfection mixture was replaced with a fresh growth medium and incubated for additional 24 hours. The cells were collected and fixed with
4\% paraformaldehyde and imaged using a fluorescent microscope (Olympus SV1000, Tokyo, Japan). The expression of GFP in HeLa cells was measured on a FACSCanto ${ }^{\mathrm{TM}}$ II flow cytometer (BD Biosciences, San Jose, CA).

\section{Cytotoxicity of PEI 25K-CA}

HeLa $\left(5 \times 10^{3}\right.$ cells/well $)$ was seeded in a 96 -well plate 1 day before transfection at $37 \mathrm{C}$. Subsequently, cells were treated with PEI $25 \mathrm{~K}-\mathrm{CA}$ and PEI $25 \mathrm{~K}$ at $37^{\circ} \mathrm{C}$ for 4 hours. At the end of this period, the mixture was replaced with $100 \mu$ of growth medium, and the cells were further incubated for 24 hours. The cell medium was replaced with $100 \mu \mathrm{l}$ of medium containing $100 \mu \mathrm{g}$ of 3-(4,5-dimethylthiazol-2-yl)-2,5-diphenyl tetrazolium bromide (Bio Basic Inc., Amherst, NY) and incubated for another 4 hours, followed by the addition of $100 \mu \mathrm{l}$ of DMSO (dimethyl sulfoxide) (Amresco, Solon, OH). The optical density was measured using a microplate reader (SpectraMax M3, Molecular Devices, San Jose, CA) at a wavelength of $570 \mathrm{~nm}$. Cytotoxicity (\%) of cells was calculated relative to cells incubated with the growth medium as a control.

\section{Growth inhibition of PEI 25K-CA/p53-EGFP complexes}

HeLa cells were seeded onto a 96-well plate at a density of $5 \times 10^{3}$ cells/well for 24 hours at $37^{\circ} \mathrm{C}$. Cells were transfected with PEI $25 \mathrm{~K}-\mathrm{CA} / \mathrm{p} 53-\mathrm{EGFP}$ complexes for 4 hours at $37^{\circ} \mathrm{C}$. Following transfection, the complexes were removed, the growth medium was filled, and the cells were incubated for another 24 hours at $37^{\circ} \mathrm{C}$. Growth inhibition of PEI 25K-CA/p53-EGFP complexes was quantified using (3-(4,5-Dimethylthiazol-2-yl)2,5-Diphenyltetrazolium Bromide) assay as described in the cytotoxicity method.

\section{Statistical analysis}

Analysis of variance was employed to analyze the difference of data. The statistically significant level was set at $p$ $<0.05$.

\section{RESULTS AND DISCUSSION}

\section{Synthesis of PEI 25K-CA}

PEI 25K-CA copolymer at a molar ratio of $1: 0.5$ was synthesized. The conjugation of CA with branched PEI $25 \mathrm{~K}$ through the amide linkage is shown in Scheme 1. The carboxylic group of CA was activated with the dicyclohexylcarbodiimide at the ratio of $1: 2(\mathrm{~mol} / \mathrm{mol})$ and conjugated with amine groups of PEI 25K. The conjugates were confirmed by FTIR spectra (Fig. 1). In PEI 25K-CA spectra, peaks for $\mathrm{N}-\mathrm{H}$ bending, $\mathrm{C}=\mathrm{O}$ absorbance band, and C-H and N-H stretching were shown at 1,615, 1,658, 2,815-2,928, and 3,260 $\mathrm{cm}^{-1}$, respectively. The presence of the $\mathrm{C}=\mathrm{O}$ absorbance band at $1,658 \mathrm{~cm}^{-1}$ indicated that the formation of an amide linkage between PEI and CA has occurred (Amjad et al., 2012).

${ }^{1} \mathrm{H}$ NMR spectra of PEI 25K-CA (Fig. 2C) showed a PEI peak at 2.5-3.4 ppm and the terminal methyl groups of CA showed a PEI peak at 0.81 and $1.07 \mathrm{ppm}$. These results confirmed the linkage between CA and PEI 25K.

\section{Characterization of PEI 25K-CA/p53-EGFP complex}

The proton sponge effect of the high buffer capacity of PEI activates lysosomal evasion (Benjaminsen et al., 2013). Buffer 


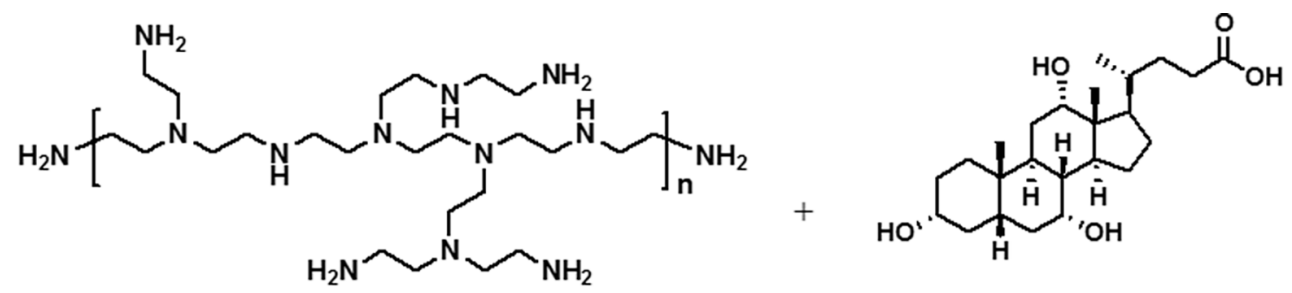

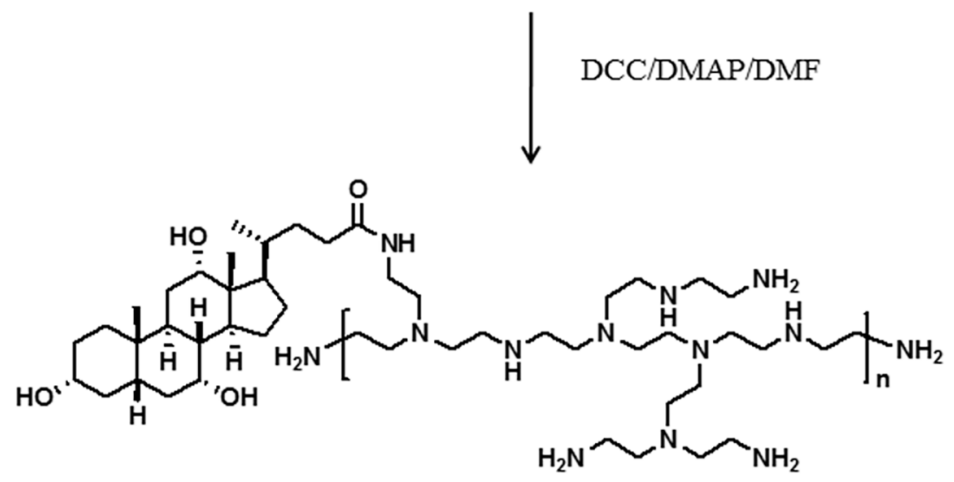

Scheme 1. Synthesis of PEI 25K-CA.

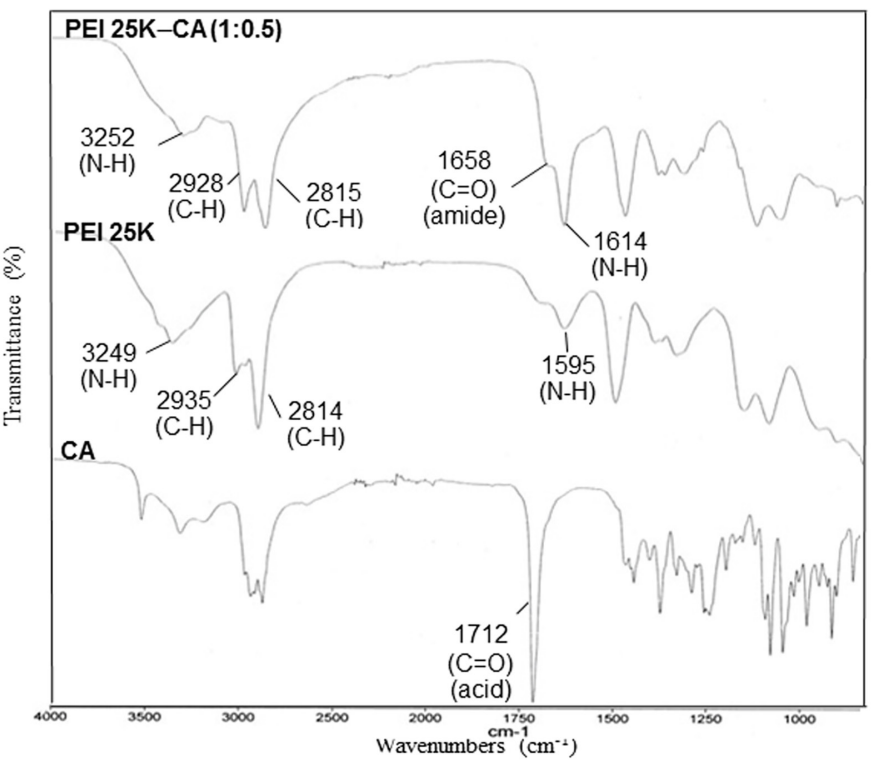

Figure 1. FTIR spectrum of CA, PEI 25K, PEI 25K-CA.

capacity is calculated at a high region resistance of $\mathrm{pH}$ change by the amount of acid divided by the change of $\mathrm{pH}$ (Sinko, 2006). From the curve of Figure 3, PEI 25K had a high region resistance of $\mathrm{pH}$ change from $7.01 \pm 0.07$ to $7.77 \pm 0.12$ with the amount of hydrochloric acid of $1.5 \times 10^{-3}$ mole; thus, the buffer capacity of PEI 25K solution was $0.002 \pm 0.0002$. PEI 25K-CA solution had a buffer capacity of $0.0024 \pm 0.0001$. The buffer capacity of PEI 25K-CA and PEI 25K solution was not significantly different. Benjaminsen et al. (2013) demonstrated that the buffer capacity of branched PEI $25 \mathrm{~K}$ was significantly higher than that of water at the $\mathrm{pH}$ of 3-7. Lu et al. (2014) exhibited that chitosan-graft-PEI had a buffer capacity less than PEI.
PEIs are able to efficiently compress nucleic acid due to their large amount of partly protonated amine groups (Benjaminsen et al., 2013). Figure 4 shows PEI 25K-CA/p53-EGFP complex formation analyzed by agarose gel electrophoresis. PEI 25K-CA and PEI $25 \mathrm{~K}$ formed complete complexes with p53-EGFP at a polymer and DNA ratio above $0.25 / 1$. Our study showed that PEI-CA had the ability to complex plasmid DNA as efficiently as PEI. Lu et al. (2014) exhibited that chitosan-graft-PEI had more efficient DNA condensing capacity than chitosan.

The zeta potential of PEI 25K-CA/p53-EGFP was lower than that of PEI $25 \mathrm{~K} / \mathrm{p} 53$-EGFP, and the particle size of PEI $25 \mathrm{~K}$ CA/p53-EGFP was significantly smaller than that of PEI $25 \mathrm{~K} /$ p53-EGFP (Fig. 5). The particle size of PEI25K/p53-EGFP was dependent on the CA substitution. Han et al. (2018) showed that nucleobase-modified polyamidoamine compacted plasmid DNA and formed nanosized particles. Lu et al. (2014) exhibited that the zeta potential and particle size of chitosan-graft-PEI were dependent on the polymer/DNA ratio.

\section{Transfection of PEI 25K-CA/p53-EGFP complexes and gene expression}

Figure 6 shows the GFP expression of PEI 25K-CA/ pEGFP and PEI 25K/pEGFP complexes visualized by fluorescent microscopy. The mean of GFP expression by PEI 25K-CA/p53EGFP and PEI25K/p53-EGFP complexes was not significantly different (Fig. 7). The high transfection efficiency of PEI 25K was proved by its "proton sponge" hypothesis of its high buffer capacity (Benjaminsen et al. 2013). Our study showed that PEI 25K-CA had transfection capability efficient as unconjugated PEI in HeLa cells. Tong et al. (2013) depicted that $\mathrm{PEI}_{600}-\beta$-cyclodextrin had transfection efficiency equivalent to PEI $25 \mathrm{~K}$ in mesenchymal stem cells. Oh et al. (2017) exhibited that deoxycholic acid-conjugated PEI had higher transfection efficiency than PEI in Neuro2A cells. Transfection efficiency of chitosan-graft-PEI was higher than that 


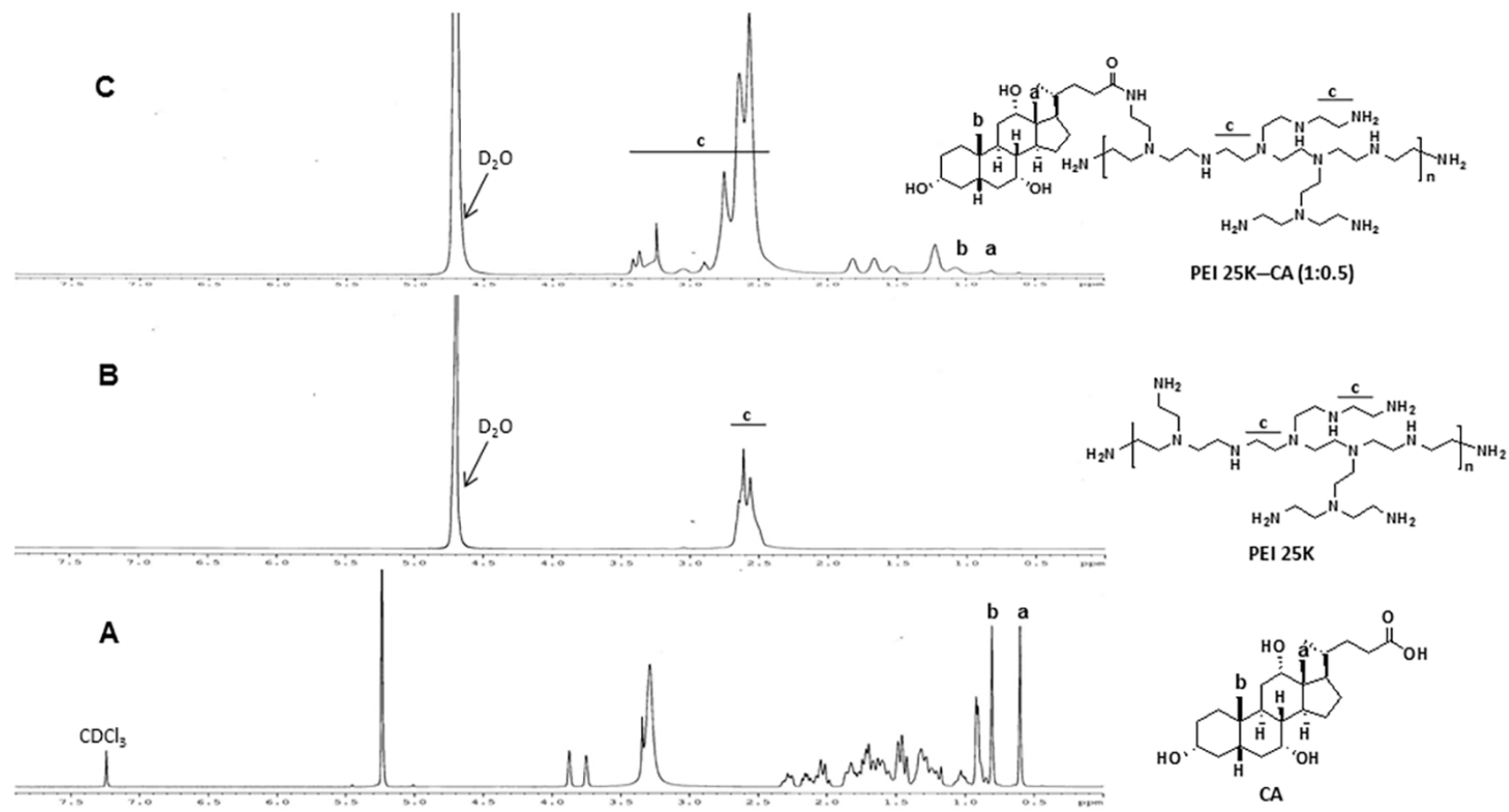

Figure 2. ${ }^{1} \mathrm{H}$ NMR spectrum of CA (A), PEI 25K (B), PEI 25K-CA.

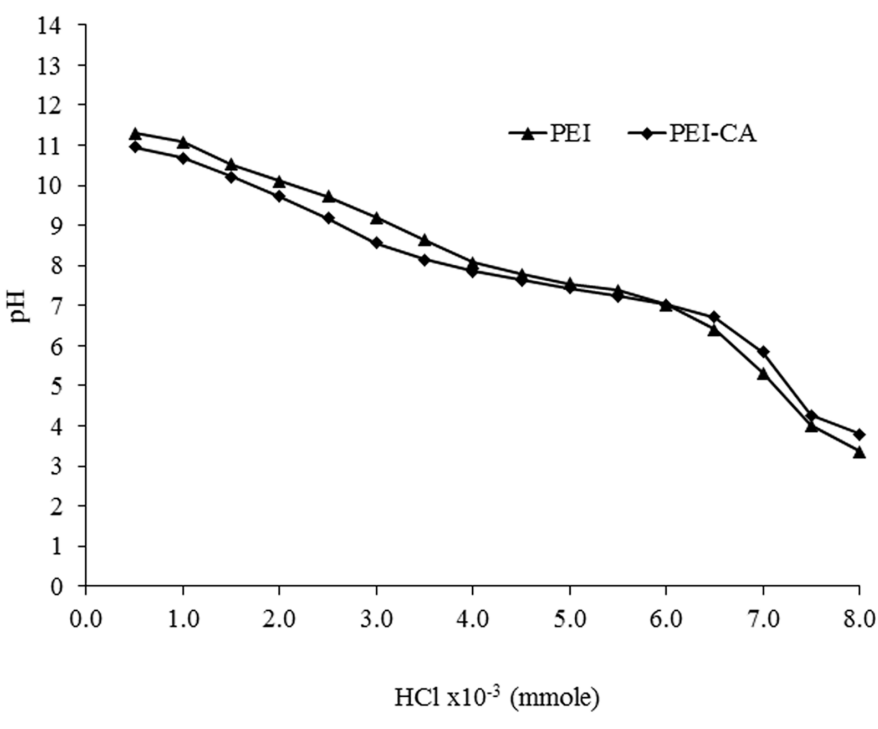

Figure 3. Buffer capacity of PEI 25K-CA and PEI 25K solution titrated with 0.1 $\mathrm{N}$ hydrochloric acid solution by acid-base titration.

of ungrafted PEI in primary chondrocyte and synoviocyte cells and dependent on the polymer/DNA ratio (Lu et al., 2014).

\section{Cytotoxicity of PEI25K-CA}

Cytotoxicity of PEI 25K-CA and PEI $25 \mathrm{~K}$ is shown in Figure 8. The cytotoxicity of PEI 25K-CA and PEI 25K increased with an increasing amount of PEI $25 \mathrm{~K}$ at the polymer concentration of $1-16 \mu \mathrm{g} / \mathrm{ml}$. At the polymer concentration of $1 \mu \mathrm{g} / \mathrm{ml}$, the cell viability of PEI 25K-CA was not different from the untreated cells. At the polymer concentration of $2 \mu \mathrm{g} / \mathrm{ml}$, the cytotoxicity of PEI

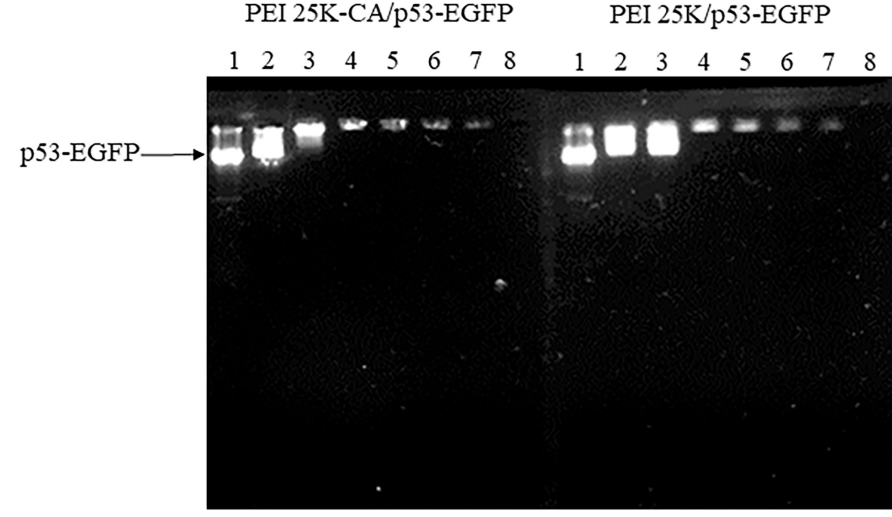

Figure 4. Gel electrophoresis analysis of PEI 25K-CA/p53-EGFP and PEI 25K/ p53-EGFP complexes on $1 \%$ agarose gel (a). Lane 1: free p53-EGFP $(0.25 \mu \mathrm{g})$. Lanes 2-8: polyplex at polymer-to-DNA ratios of $0.125,0.25,0.375,0.5,1,2$, and 4 , respectively.

25K-CA was significantly lower than that of PEI 25K. Cytotoxicity of PEI 25K-CA in HeLa cells increased with the increase of polymer concentration (Fig. 8). PEI 25K had a severe cytotoxic effect (Thomas et al., 2019). Several investigations attempted to synthesize PEI derivatives to decrease their cytotoxicity (Han et al., 2018; Lu et al., 2014; Oh et al., 2017). Han et al. (2018) showed that nucleobase-modified polyamidoamine decreased the cytotoxicity in HeLa cells because of decreased positive charge density on polymer surface. Oh et al. (2017) exhibited that deoxycholic acid-conjugated PEI had less cytotoxicity than PEI in Neuro2A cells. Lu et al. (2014) showed that the cytotoxicity of chitosan-graft-polyethylenimine was lower than that of ungraftedPEI in primary chondrocyte and synoviocyte cells. 
a)

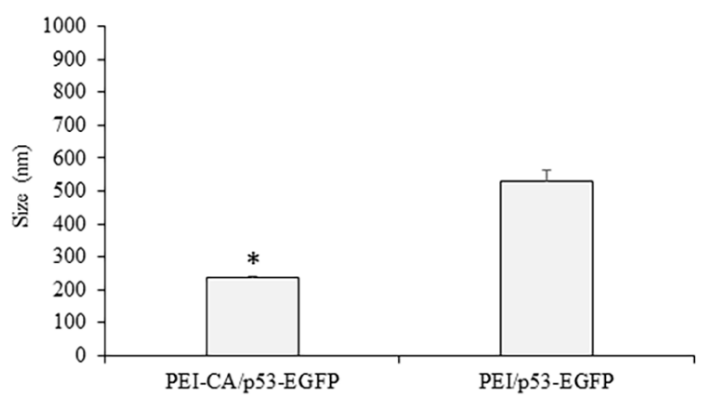

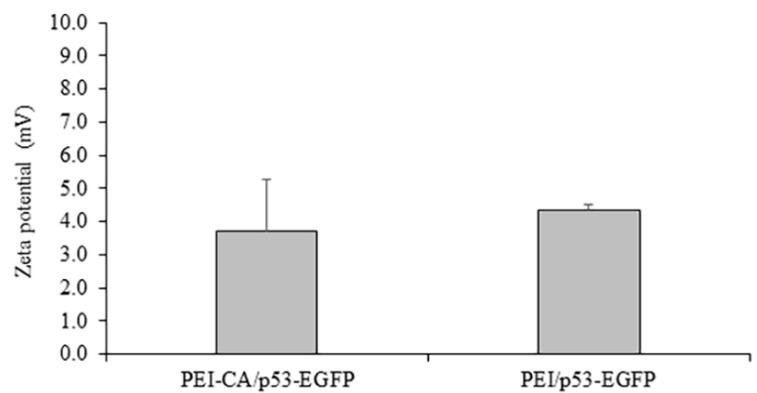

Figure 5. Particle size (a) and zeta potential (b) of PEI 25K-CA/p53-EGFP and PEI 25K/p53-EGFP. ${ }^{*} p<0.05$ when compared with PEI 25K/p53-EGFP.

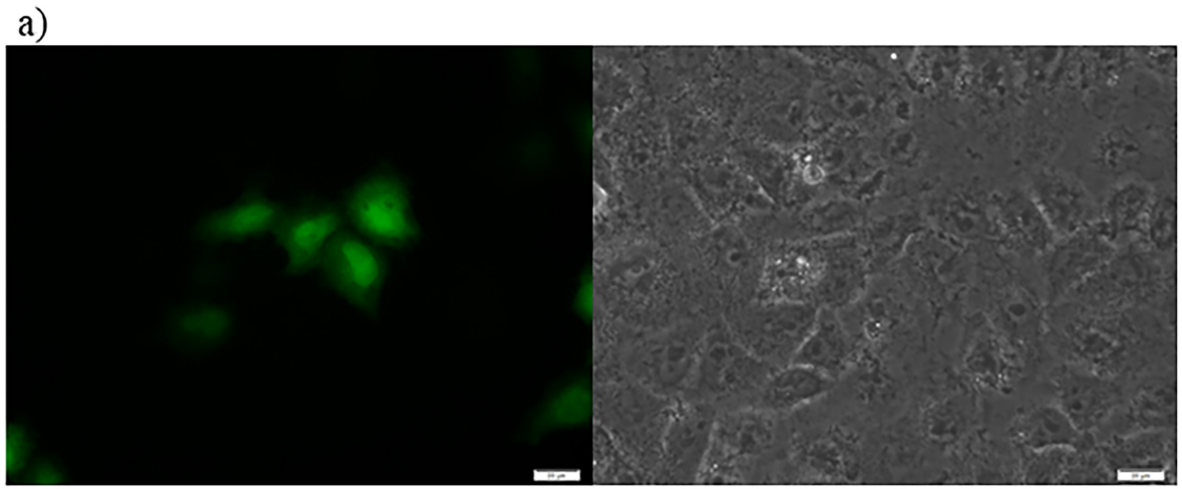

b)

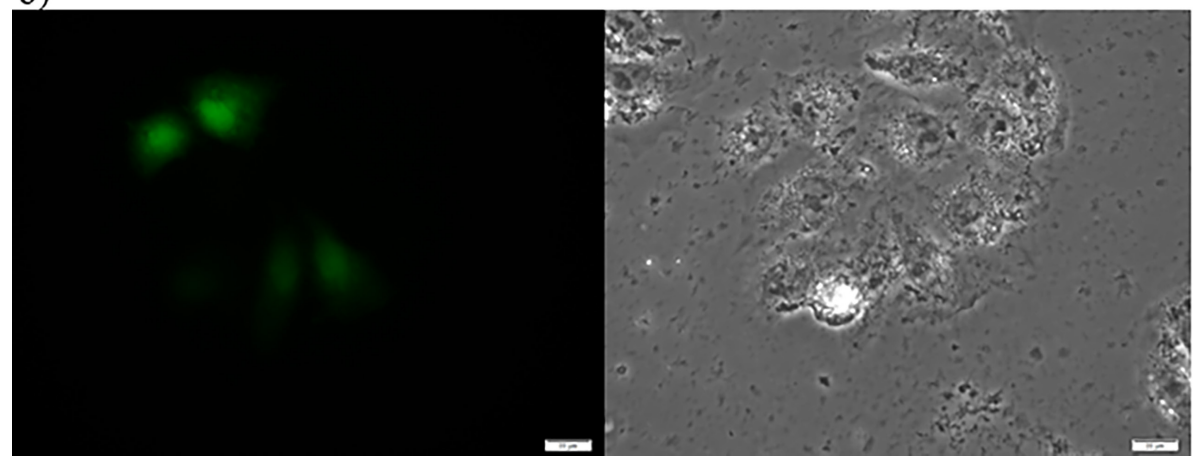

Figure 6. Green fluorescent protein expressed in HeLa cells transfected by PEI 25K-CA/pEGFP (a) and PE $25 \mathrm{~K} / \mathrm{pEGFP}$ (b) evaluated by fluorescent microscopy.

a)

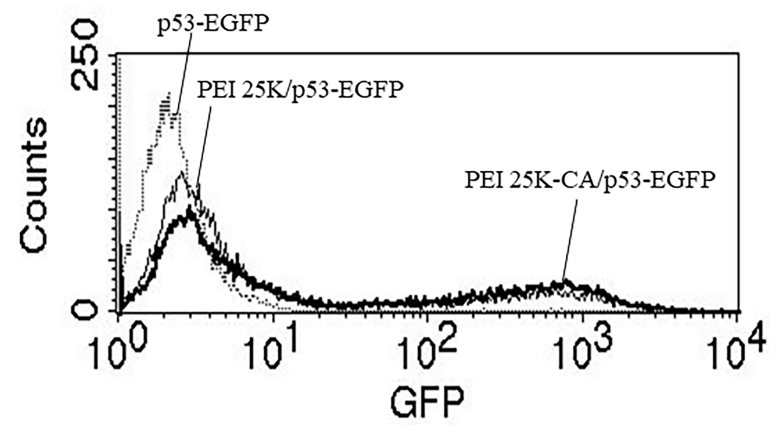

b)

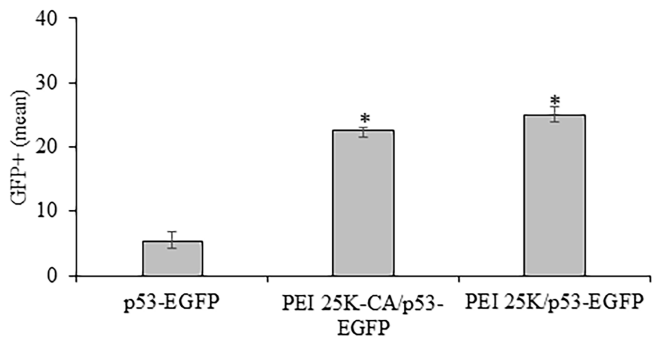

Figure 7. Flow cytometry analysis (a) and GFP+ (b) of HeLa cells transfected by PEI 25K-CA/p53-EGFP and PEI 25K/p53-EGFP. $* p<0.05$; significantly different from $\mathrm{p} 53-\mathrm{EGFP}$. 


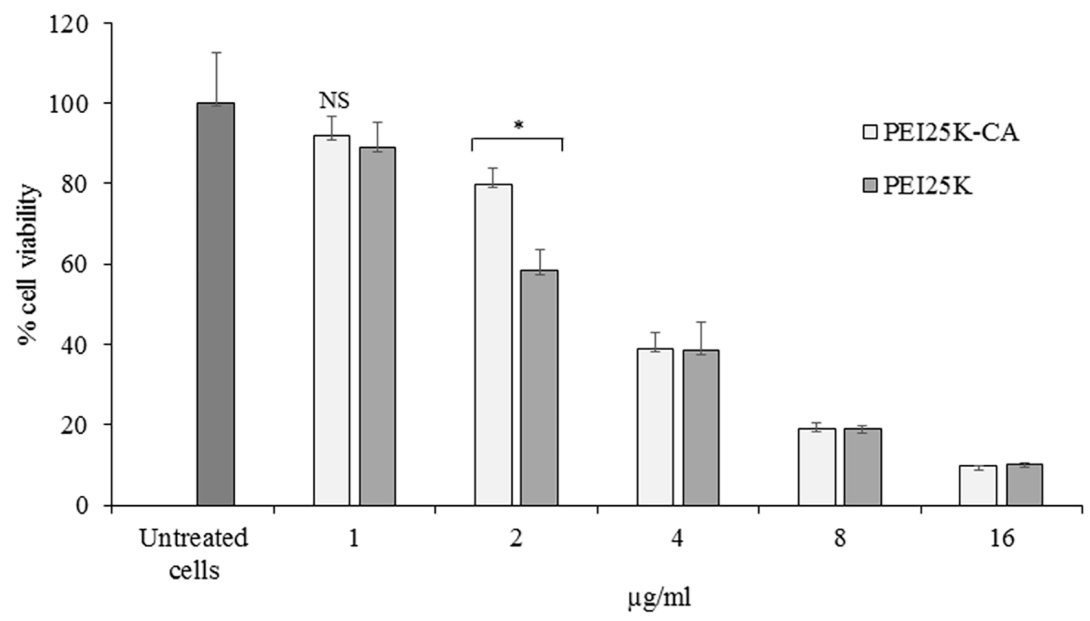

Figure 8. Cytotoxicity of PEI $25 \mathrm{~K}-\mathrm{CA}$ and PEI $25 \mathrm{~K}$ in HeLa cells. ${ }^{*} p<0.05$; significantly different from PEI 25K/p53-EGFP.

a)

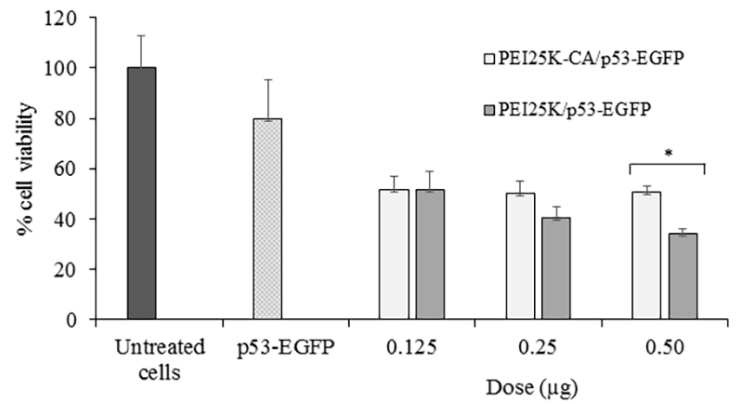

b)

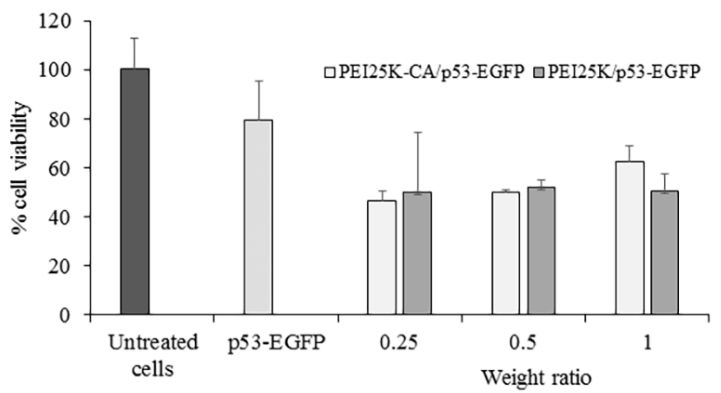

Figure 9. Growth inhibition of PEI 25K-CA/p53-EGFP and PEI 25K/p53-EGFP in HeLa cells. ${ }^{*} p<0.05$; significantly different from PEI 25K/p53-EGFP.

a)

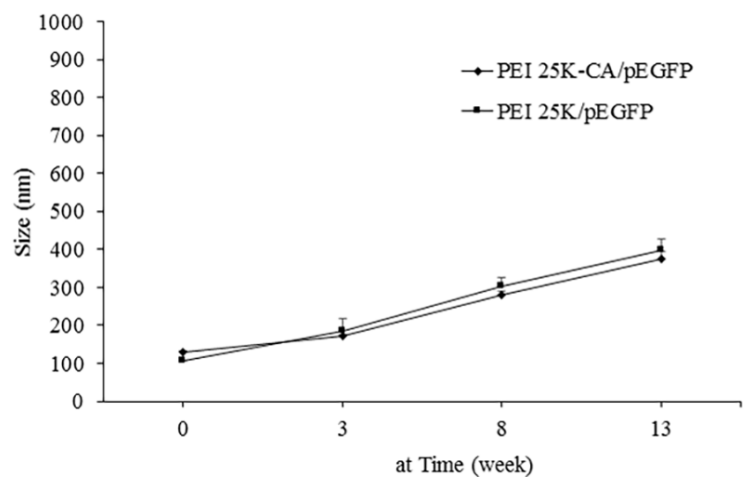

b)

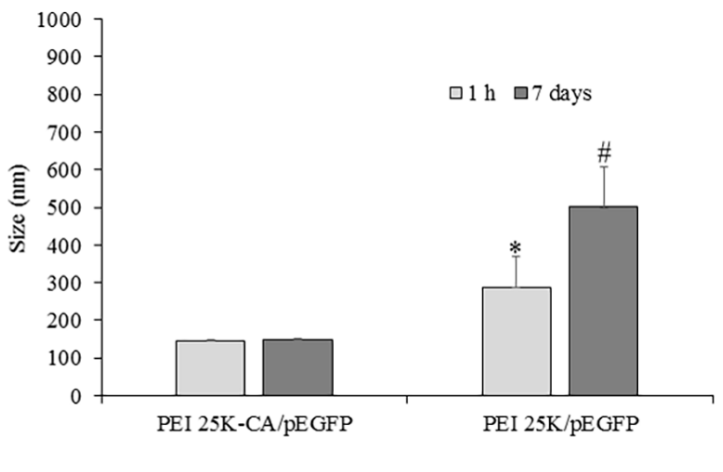

Figure 10. Colloidal stability of PEI 25K-CA/pEGFP and PEI 25K/pEGFP stored in deionized water (a) and in $10 \%$ bovine serum albumin (b) at $4{ }^{\circ} \mathrm{C} \pm 2{ }^{\circ} \mathrm{C} .{ }^{*} p<0.05$; significantly different from PEI $25 \mathrm{~K}-\mathrm{CA} / \mathrm{pEGFP}$. ${ }^{* *} p<0.05$; significantly different from at 1 hour.

\section{Growth inhibition of PEI25K-CA/p53-EGFP complexes}

Figure 9 shows the growth inhibition of PEI 25K-CA/ p53-EGFP complexes and PEI 25K/p53-EGFP complexes in HeLa cells. The growth inhibition ability of PEI25K-CA/p53-
EGFP and PEI25K/p53-EGFP was significantly higher than that of cells treated with p53-EGFP. The growth inhibition ability of PEI25K-CA/p53-EGFP complexes was similar to that of PEI $25 \mathrm{~K} / \mathrm{p} 53$-EGFP complexes at the polymer/DNA ratio of 0.25 , 
0.5 , and 1 and that of the p53-EGFP dose of 0.125 and $0.25 \mu \mathrm{g}$. At the p53-EGFP dose of $0.5 \mu \mathrm{g}$, the growth inhibition ability of PEI 25K/p53-EGFP complexes was significantly higher than that of PEI 25K-CA/p53-EGFP complexes. Our study depicted that the growth inhibition of PEI 25K-CA/p53-EGFP complexes at the low dose of p53-EGFP of 0.125 and $0.25 \mu \mathrm{g}$ and the PEI/ DNA ratios of 0.25 and 0.5 was closed to that of PEI $25 \mathrm{~K} / \mathrm{p} 53-$ EGFP complexes. Han et al. (2018) reported that nucleobasemodified polyamidoamine could deliver p53 and inhibit HeLa cell proliferation. Chen et al. (2019a) reported that lauric acid-couple $\mathrm{PEI} / \mathrm{pTRIAL}$ nanoparticles induces apoptosis in mouse B16F10 melanoma cells. In our previous study, PEI-CA formed complexes with p53-EGFP and bcl-2 AS-ODN and was evaluated in HeLa cells (Weecharangsan et al., 2017).

\section{Colloidal stability of PEI25K-CA/p-EGFP complexes}

Figure 10 shows the particle size of PEI25K-CA/pEGFP complexes and PEI25K/pEGFP complexes in deionized water stored at $4{ }^{\circ} \mathrm{C} \pm 2{ }^{\circ} \mathrm{C}$. The particle size of PEI25K-CA/pEGFP complexes and PEI25K/p53-EGFP complexes at the starting time was $128.6 \pm 5.5$ and $105.9 \pm 1.5 \mathrm{~nm}$, respectively. The particle size of both complexes increased with the period time of 13 weeks (Fig. 10a). In 10\% bovine serum albumin solution, PEI25K/ pEGFP complexes had particle size significantly bigger than that of PEI25K-CA $/ \mathrm{pEGFP}$ complexes at the time of 1 hour and that of PEI25K-CA/pEGFP complexes at the time of 7 days.

\section{CONCLUSION}

This study concluded that PEI 25K-CA had efficient gene delivery as PEI and had lower cytotoxicity and more colloidal stability than those of PEI25K. PEI 25K-CA could be used as an efficient delivery for plasmid DNA.

\section{ACKNOWLEDGMENTS}

We are thankful to Olympus Bioimaging Center, Mahidol University, for fluorescence microscope imaging.

\section{CONFLICT OF INTEREST}

The authors have no conflict of interest to declare.

\section{FUNDING}

This study was funded by Thailand Research Fund, the Office of the Higher Education Commission, and Srinakharinwirot University (MRG5680048).

\section{PUBLISHER'S NOTE}

This journal remains neutral with regard to jurisdictional claims in published institutional affiliation.

\section{REFERENCES}

Amjad, MW, Amin, MCIM, Katas H, Butt AM. Doxorubicinloaded cholic acid-polyethyleneimine micelles for targeted delivery of antitumor drugs: synthesis, characterization, and evaluation of their in vitro cytotoxicity. Nanoscale Res Lett, 2012; 7:687.

Benjaminsen RV, Mattebjerg MA, Henriksen JR, Moghimi SM, Andresen TL. The possible "proton sponge" effect of polyethylenimine (PEI) does not include change in lysosomal pH. Mol Ther, 2013; 21:149-57.
Cao Y, Tan YF, Wong YS, Liew MWJ, Venkatraman S. Recent advances in chitosan-based carriers for gene delivery. Mar Drugs, 2019; $17: 381$.

Chen K, Cao X, Li M, Su Y, Li H, Xie M, Zhang Z, Gao H, $\mathrm{Xu}$ X, Han Y, Zhou J, Wang W. A trail-delivered lipoprotein-bioinspired nanovector engineering stem cell-based platform for inhibition of lung metastasis of melanoma. Theranostics, 2019; 9:2984-98.

Chen K, Xin X, Qiu L, Li W, Guan G, Li G, Qiao M, Zhao X, $\mathrm{Hu}$ H, Chen D. Co-delivery of p53 and MDM2 inhibitor RG7388 using a hydroxyl terminal PAMAM dendrimer derivative for synergistic cancer therapy. Acta Biomater, 2019; 100:118-31.

Han H, Chen W, Yang J, Liang X, Wang Y, Li Q, Yang Y, Li K. Inhibition of cell proliferation and migration through nucleobase-modified polyamidoamine-mediated p53 delivery. Int $\mathrm{J}$ Nanomedicine, 2018; 13:1297-311

Hao F, Li Y, Zhu J, Sun J, Marshall B, Lee RJ. Polyethyleniminebased formulations for delivery of oligonucleotides. Curr Med Chem, 2019; 26:2264-84.

Kaiser AM, Attardi LD. Deconstructing networks of p53mediated tumor suppression in vivo. Cell Death Differ, 2001; 25:93-103.

Liufu C, Li Y, Tu J, Zhang H, Yu J, Wang Y, Huang P, Chen Z. Echogenic PEGylated PEI-loaded microbubble as efficient gene delivery system. Int J Nanomedicine, 2019; 14:8923-41.

Lu H, Dai Y, Lv L, Zhao H. Chitosan-graft-polyethylenimine/ DNA nanoparticle as novel non-viral gene delivery vectors targeting osteoarthritis. Plos One, 2014; 9:e84703.

Marchenko ND, Moll UM. Mitochondrial death functions of p53. Mol Cell Oncol, 2014; 1:e955995-8.

Oh J, Lee MS, Jeong JH, Lee M. Deoxycholic acid-conjugated polyethylenimine for delivery heme oxygenase-1 gene in rat ischemic stroke model. J Pharm Sci, 2017; 106:3524-32.

Sinko PJ. Buffer capacity. In: Martin's physical pharmacy and pharmaceutical sciences. Lippincott Williams \& Wilkins, New York, NY, pp 213-17, 2006..

Thomas TJ, Tajmir-Riahi HA, Pillai KS. Biodegradable polymers for gene delivery. Molecules, 2019; 24:3744.

Tong H, Wang C, Huang Y, Shi Q, Fernandes JC, Dai K, Tang $\mathrm{G}$, Zhang X. PEI ${ }_{600}-\beta$-cyclodextrin: a promising nanopolymer for nonviral gene delivery of primary mesenchymal stem cells. Int J Nanomedicine, $2013 ; 8: 1935-46$.

Wang $\mathrm{X}$, Niu $\mathrm{D}, \mathrm{Hu} \mathrm{C}$, Li P. Polyethyleneimine-based nanocarriers for gene delivery. Curr Pharm Des, 2015; 21:6140-56.

Weecharangsan W, Opanasopit P, Niyomtham N, Yingyongnarongkul B, Kewsuwan P, Lee RJ. Synergistic inhibition of human carcinoma cell growth via co-delivery of p53 plasmid DNA and bcl-2 antisense oligodeoxyribonucleotide by cholic acid-modified polyethylenimine. Anticancer Res, 2017; 37:6335-40.

How to cite this article:

Weecharangsan W, Niyomtham N, Yingyongnarongkul B, Opanasopit P, Lee RJ. Growth inhibition of cholic acidconjugated polyethylenimine $25 \mathrm{~K} / \mathrm{p} 53$-EGFP complexes on human carcinoma cells. J Appl Pharm Sci, 2021; 11(04): 014-021. 


\section{GRAPHICAL ABSTRACT}
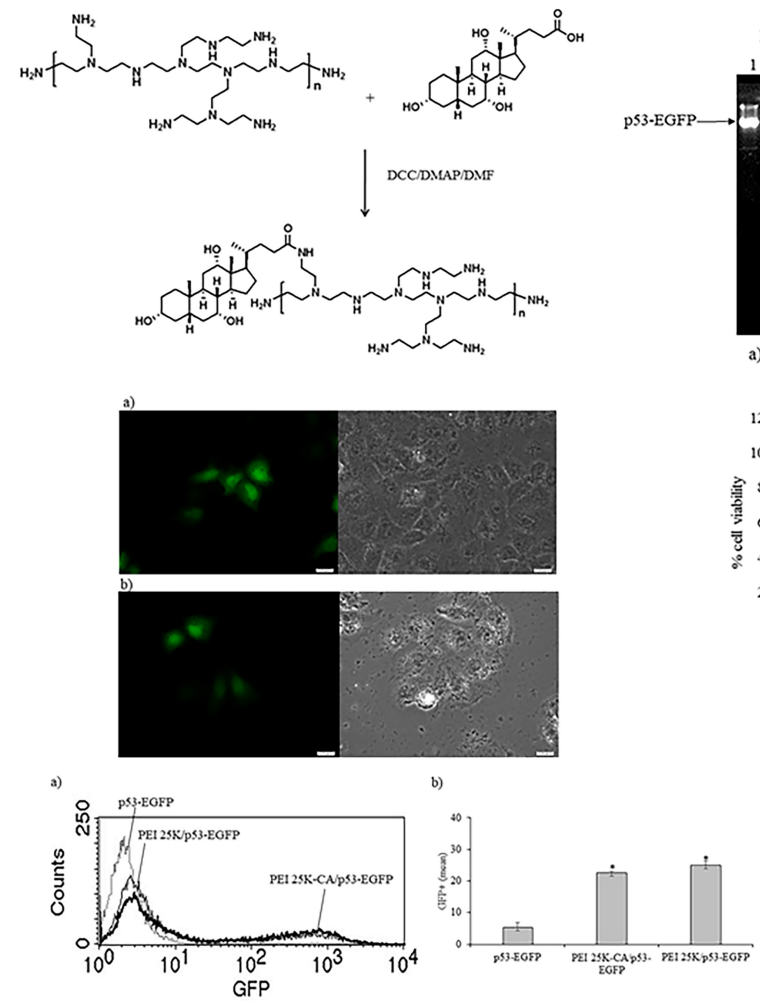
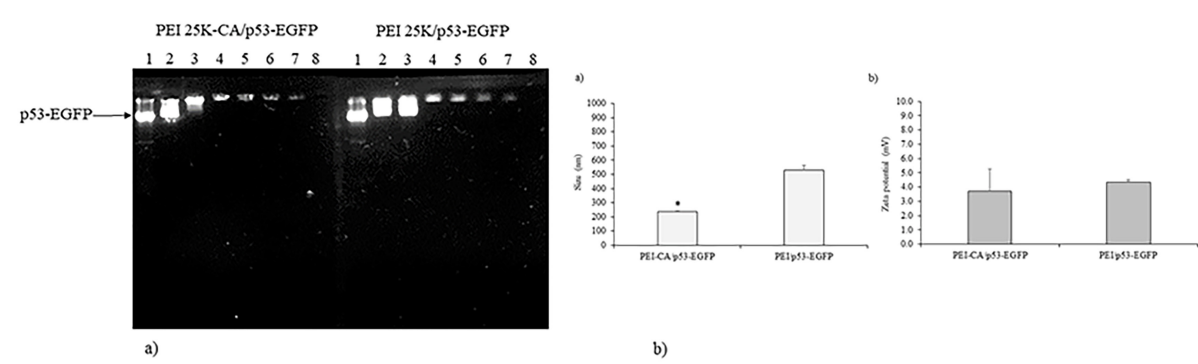

b)
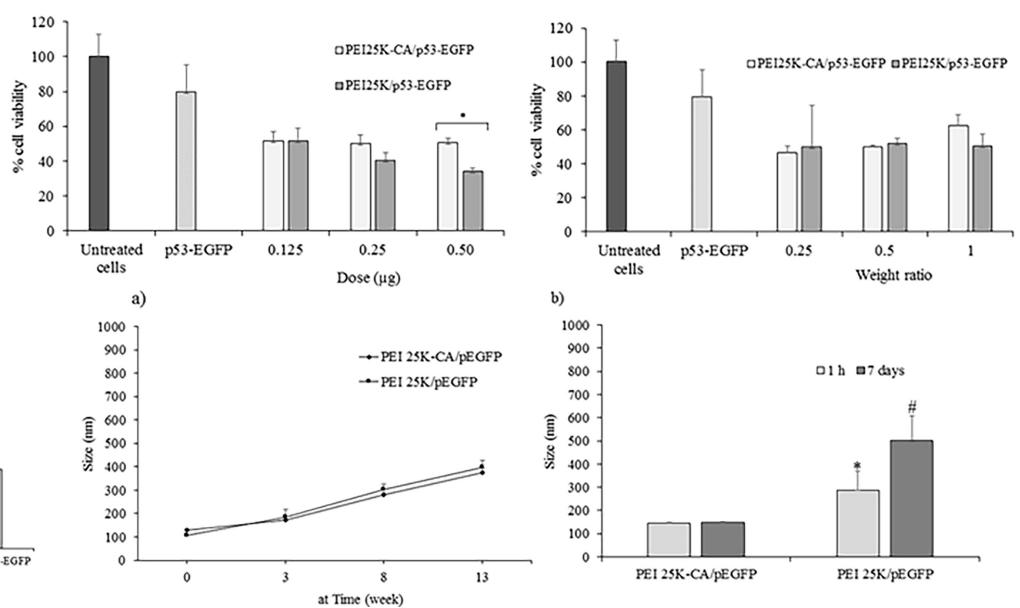